\title{
Education Mismatches in the Labor Markets and Their Impact on Wages across Sectors: Evidence from Turkey
}

\author{
Anul DUMAN (https://orcid.org/0000-0002-7615-3826), Department of Political Science, Central European \\ University, Hungary; e-mail: dumana@ceu.edu
}

\section{Emek Piyasalarında Eğitim Uyumsuzlukları ve Sektörler Arasında Ücretlere Etkisi: Türkiye Örneği}

\begin{abstract}
The incidence of mismatch and its pay effects vary not only across countries but also across sectors due to different institutional arrangements. The first aim of the paper is to estimate education mismatches in the Turkish labor market. Our second aim is to distinguish the impact of education mismatches on wages in public and private sectors. The results of the analysis show returns on overeducation are lower than required education in both sectors similar to many other country examples. Moreover, we also show that wage differences between overeducation and required education are smaller in the private sector, and through Oaxaca decomposition method most of it can be explained by endowments. Lastly, the effect of undereducation on wages differs across sectors and we conclude that human capital model is not applicable to Turkish public sector.
\end{abstract}

Keywords $\quad$ : Education Mismatch, Wages, Public, Private Sector, Oaxaca

Decomposition.

JEL Classification Codes : J24, J31, I26.

\section{$\ddot{\mathbf{O z}}$}

Eğitim uyumsuzluklarının görülme sıklığı ve kazanca etkisi hem ülkeler hem de sektörler arasında farklılık göstermektedir. Makalenin birinci amacı Türkiye emek piyasasındaki eğitim uyumsuzluklarının büyüklüğünü hesaplamaktır. İkinci amacımız ise eğitim uyumsuzluklarının ücretleri özel ve kamu sektörlerinde nasıl farklı etkilediğini ortaya koymaktır. Bulgularımıza göre fazla eğitimli olmanın getirisi her iki sektörde de diğer ülke örnekleri ile benzer şekilde gereken eğitimin getirisinden daha azdır. Ayrıca, fazla eğitim ve gereken eğitim arasındaki ücret farkının özel sektöde daha az olduğu ve Oaxaca ayrıştırma yöntemi ile bu farkın büyük oranda donatım ile açıklanabileceği gösterilmiştir. Son olarak, az eğitimli olmanın sektörler arasında ücretleri farklı etkilediği ve Türkiye kamu sektöründe beşeri sermaye modelinin geçerli olmadığı da sonucuna da varılmıştır.

Anahtar Sözcükler $\quad$ : Eğitim Uyumsuzluğu, Ücretler, Kamu, Özel Sektör, Oaxaca Ayrıştırması. 
Duman, A. (2018), "Education Mismatches in the Labor Markets and Their Impact on

Wages across Sectors: Evidence from Turkey”, Sosyoekonomi, Vol. 26(37), 227-242.

\section{Introduction}

Studying education mismatches can be informative for developing countries such as Turkey given the increasing but still low level of human capital. Moreover, education and skill deficits are stated to be one of the main issues by employers. Hence, matching formal education with the requirements of jobs can avoid underutilization of human resources and maximize productivity. There is a rich literature measuring the education mismatches in the labor market, and three main approaches are used to identify the level of overeducation and undereducation in an economy. In the job analysis method, occupational classifications are formed to evaluate whether employees have the required education that is necessary for the job (McGoldrik \& Robust, 1996). For example, US Dictionary of Occupational Titles (DOT) is the most commonly used reference to estimate the degree of overeducation and undereducation in a given time period. The second approach, realized match, considers an ad-hoc value such as one standard deviation from the mean or the mode value of required education for a particular job as the basis for mismatch (Verdugo \& Verdugo, 1989; Kiker et al., 1997). While both of these measurements are objective, there are also subjective approaches where workers provide their opinion about the match between their education and job requirements (Allen \& van der Velden, 2001; Verhaest \& Omey, 2006).

Unsurprisingly, the extent of labor market mismatches are found to differ by country and measurement adopted. For example, the lowest incidence of overeducation was observed in Finland with 11.1\% and the highest incidence was observed in Austria with 58\% (ILO, 2014). Besides, it has been argued that overeducation persists in countries such as Italy and Japan whereas in Belgium and the UK, it is temporary and recent graduates do not continue to be mismatched at the same rate (Meroni \& Vera-Toscano, 2017). Share of mismatched workers in Egypt went down from 51\% to 42\% over time (El-Hamidi, 2008). Even though the incidence of education mismatch is varied across countries and the aforementioned methods, its negative impact on wages are well established in the literature. It has been affirmed in a number of studies that returns to overeducation are positive but smaller than the premium for required education, and returns to undereducation are negative but not always significant for all samples (Hartog, 2000; Galasi, 2008; Leuven \& Oosterbeek, 2011). Yet, the magnitude of wage penalty for mismatched employees differs between countries and sectors.

While studies analyzing education mismatches in developed countries are plenty, the research focusing on Turkey is extremely sparse. In a recent paper, high levels of undereducation and overeducation are detected in Turkey, and it has been argued that even low skilled occupations such as subsistence agricultural and fishery suffers from mismatches (Mercan et al., 2015). With a different dataset and estimation methodology, the incidence of overeducation is estimated to be increasing between 1994 and 2002 from $20.3 \%$ to $24.6 \%$ with the mode measure and from $13.1 \%$ to $15.6 \%$ with the mean measure. Moreover, it has been shown that overeducation generates lower returns than required education (Filiztekin, 2011). Another study argues that the share of overducated workers with mean index is nearly $23 \%$ and undereducated workers is $14.5 \%$ for $2006-2010$. With mode index the respective shares go up to $29.8 \%$ and $17.8 \%$ for the same period. However, according to the paper there 
is no statistically significant effect of education mismatch on wages in Turkey after unobservable heterogeneity and measurement errors are accounted for (Acar, 2016). Lastly, $33.7 \%$ of all Turkish employees are claimed to be overeducated and $20.4 \%$ are undereducated between 2009 and 2012, and the negative effect of mismatches on earnings are confirrmed as well (Orbay \& Aydede, 2015).

The inconsistent results in these studies are partly due to various datasets and methodologies utilized. Hence, our first contribution is to provide a more systematic examination of the Turkish case where education mismatches are argued to be large. Second, as mentioned previously the required level of education can be defined subjectively or objectively, and depending on the choice of the approach incidence of mismatch can differ significantly. There is no analysis of education mismatch through workers' self-assessment in Turkey, and the other contribution of the paper is to offer subjective examination using European Working Conditions Survey (EWCS) and objective examination using Household Labor Force Survey (HLFS). Third, we look at the impact of education mismatches on wage determination in Turkey across sectors. Given the institutional differences between private and public sectors the relationship between education mismatches and wages is expected to be distinct as well. Our findings extend the analysis for Turkey and reveal that human capital model is not applicable to Turkish public sector as mismatches are more substantial and can not be explained by endowments.

The paper is organized as follows. In the second section, the formation of subjective and objective measures is described in more detail and incidences of mismatches based on different estimates for Turkey are presented. The third section first outlines the theoretical models and empirical methodology used to evaluate the impact of mismatches on wages and then discusses the findings. In the final section, concluding remarks are offered and few policy implications are expressed.

\section{Subjective and Objective Education Mismatches in Turkey}

As mentioned in the introduction there are various approaches to measure education mismatches in labor markets. Subjective methods are based on survey questions that ask employees about perceptions regarding how much of their education or skills are utilized in their current job. There are also studies that look into the required education level for the job under consideration and education that is required to the job in addition to time of preparation to perform (Allen \& van der Velden, 2001). Generally, subjective techniques produce larger mismatches than objective measures, and the primary reason is the measurement errors that arise from inflating self-status by respondents. Moreover, employees might not be adequately informed about the necessary levels of education for the tasks they conduct (Flisi et al., 2017). Despite these weaknesses, subjective measures are widely used in the literature because they are broader in scope and simpler to estimate. There are many international surveys that allow the researchers to compare different labor markets. Besides, subjective measures offer a direct understanding of workers' perspectives on the utilization of their education and skills. 
To our best knowledge there is no inspection of education mismatches in Turkey with subjective methods. For this purpose, we employ the latest data from EWCS, which leaves us with 2000 individuals. Out of these $72.15 \%$ of are male and the rest are female, and in total $68.25 \%$ of the participants are salaried employees. In order to calculate the ratio of subjectively mismatched individuals, we use the question asking whether there is any need for further training to cope well with duties or whether the skills of the employee are sufficient for more demanding duties. As can be seenFigure 1, nearly $25.5 \%$ of all respondents declared that they have skills that are more than required for their current employment. On the other hand, 5.7\% of them stated that they need further education and hence can be considered as undereducated. The share of matched employees is more than $68 \%$ in Turkey according to the subjective measure. These figures are in line with other country examples such as $23 \%$ of overeducation in Austria and 24\% in Belgium (Flisi et al., 2017). There is no significant difference across genders and while nearly $26 \%$ of males are overeducated, among females $24.1 \%$ have greater education than needed for their tasks.

Figure: 1

\section{Share of Education Mismatches}

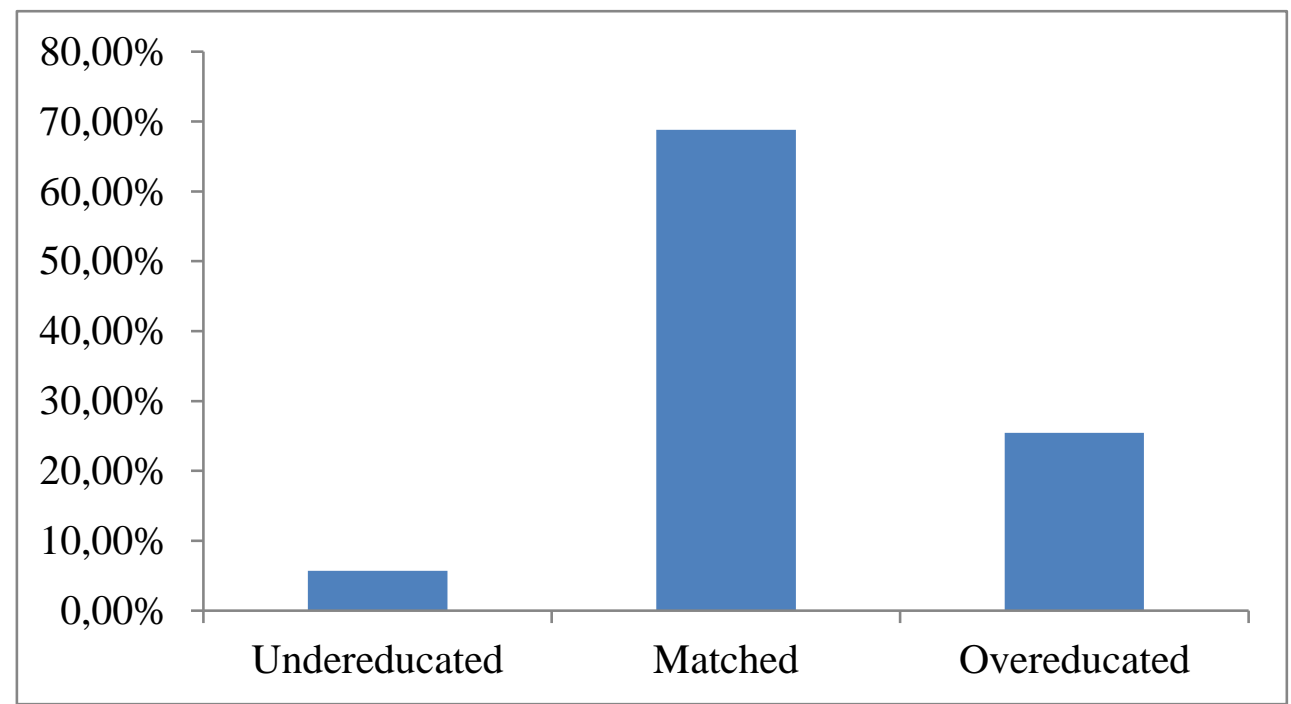

Source: Author's calculations based on ECWS (2015)

Figure 2 shows the education mismatches across private and public sectors and it is clear that public sector has much higher portion of undereducated workers with $10.6 \%$ but the share of overeducated workers is lower than the private sector, approximately $18.6 \%$. The private sector in Turkey appears to be suffering more from education mismatches as $26 \%$ of survey respondents argued that their training is more than what is required in their employment. However, the degree of match is quite similar across sectors with $69.7 \%$ in the private sector and $70.8 \%$ in the public sector. The mismatch, estimated by subjective approach, points out that undereducation is more common in the public sector whereas 
overeducation is a bigger problem in the Turkish private sector. These findings indicate that corporations are not able to utilize employees' training adequately, and this situation coupled with high levels of unemployment among university graduates pose major issues for labor markets.

\section{Figure: 2}

\section{Share of Education Mismatches across Sectors}

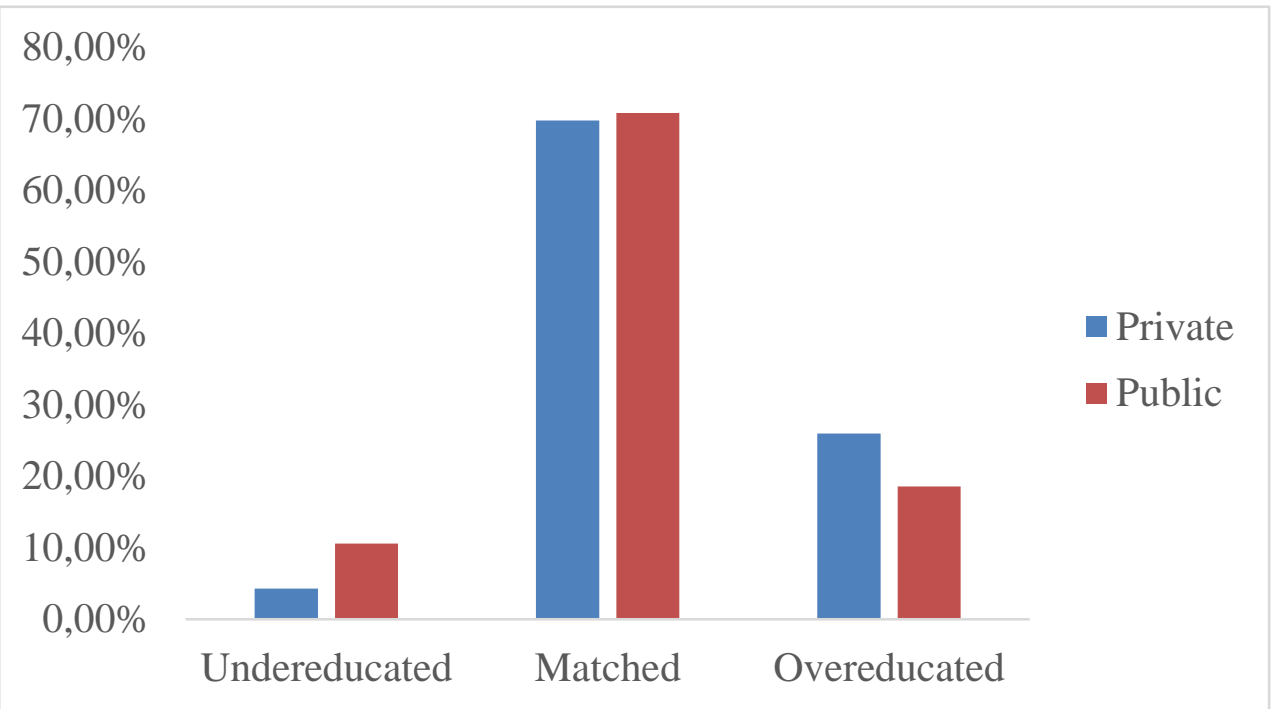

Source: Author's calculations based on ECWS (2015)

The objective methods to investigate education mismatches start with identification of required level of education in an occupation, and in most studies International Standard Classification of Occupations (ISCO) and International Standard Classification of Education (ISCED) are used to determine the required levels. According to the mean measure, overeducated workers are the ones that have longer years of schooling than the mean years for a particular occupational category (Verdugo \& Verdugo, 1989). The mode measure, on the other hand, considers the mode year of schooling for each occupational group and estimate workers that have lower and higher years of schooling based on the mode value (Kiker et al., 1997). We use both mean and mode measures to assess education mismatches in the Turkish labor market, and required level of education at ISCO-08 1-digit level is computed by adding mean or mode and one standard deviation. The most recent data from HLFS is used in the analysis, which provides a total of 104,378 salaried workers. Among these $75.62 \%$ are male and the rest are female employees, and nearly $24.5 \%$ of the entire sample have tertiary education. Figure 3 presents the share of mismatches for both measures, ss shown in previous studies, mode measure gives considerably higher mismatch ratios, which is also the case in the Turkish context. There are $16 \%$ overeducated workers according to the mean approach whereas the share increases to nearly $26 \%$ with the mode approach. 
While no significant difference is observed between genders, incidence of overeducation increases with schooling and peaks among university graduates.

Figure: 3

\section{Objective Education Mismatches}

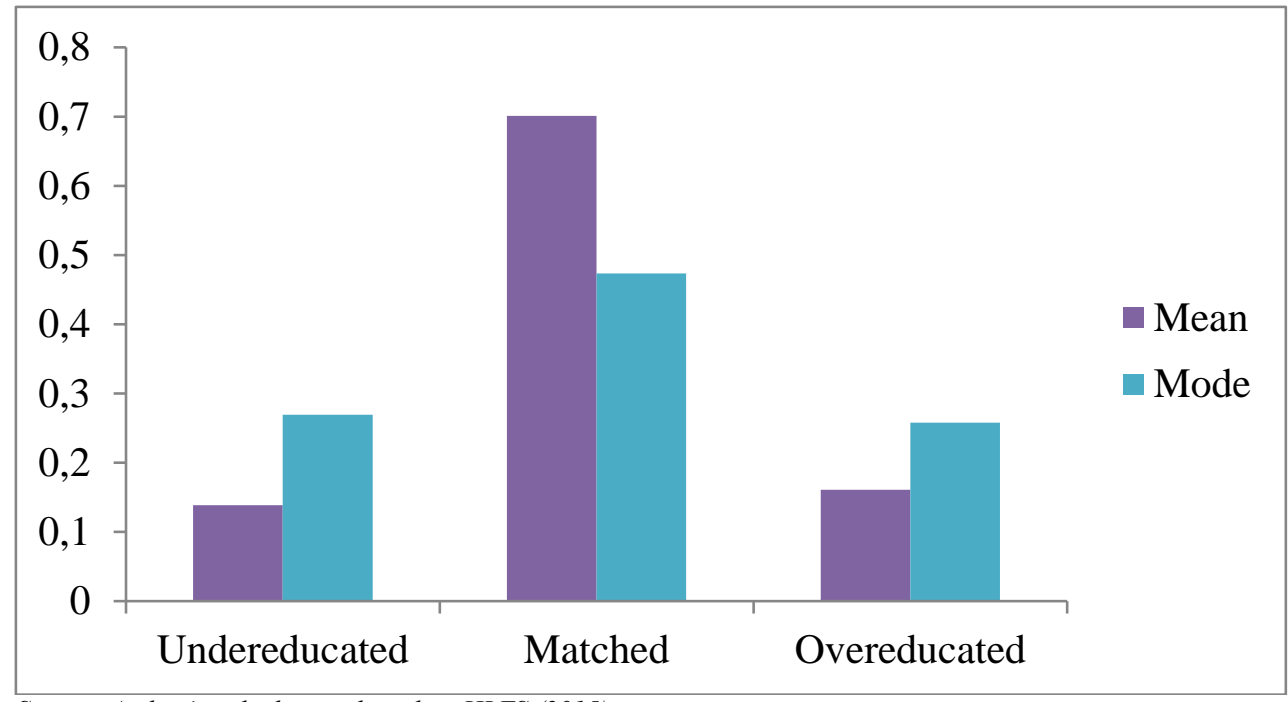

Source: Author's calculations based on HLFS (2015)

To analyze the sectoral variation, mean approach is utilized and Figure 3 portrays the share of overeducated and undereducated employees in Turkey. While education mismatches estimated by objective approach are lower in Turkey with compared to subjective measure, they provide a very similar picture for sectors. In public sector as opposed to the subjective measure, objective approach suggests a higher portion of overeducated workers with $19.42 \%$. The same ratio decreases to almost $15.5 \%$ in private sector but incidence of undereducation happens to be higher with $13.3 \%$. This is a sign of relatively better utilization of skills in the private sector but at the same time lack of qualified employees for certain jobs. On the other hand, a sizable part of public sector employees don't need the schooling they acquired for their current positions. 


\section{Figure: 4}

\section{Objective Education Mismatches across Sectors}

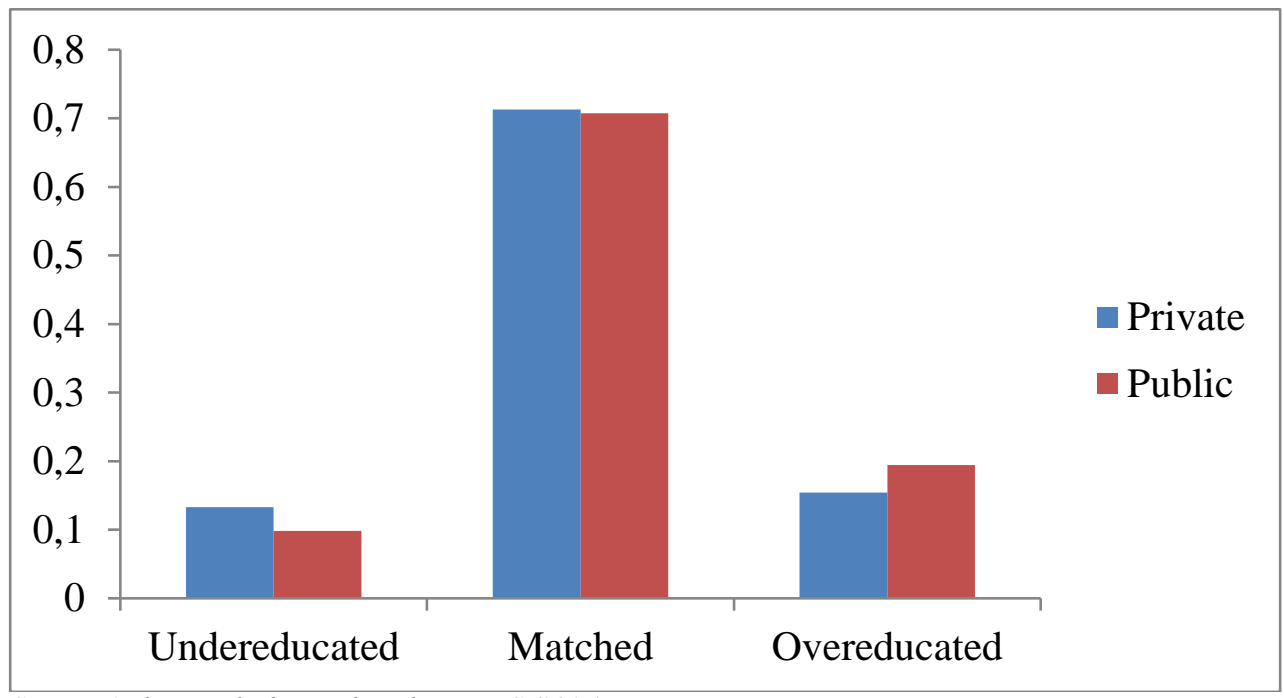

Source: Author's calculations based on HLFS (2015)

In addition to varied education mismatches, wages also significantly differ across sectors. As can be seen from Figure 5 private sector wage distribution is closer to a normal distribution and the mean monthly wage is much lower, around 1,383 TL. In public sector, the average wage increases to 2,637 TL per month but the highest wages remain below the private sector. Given the educational mismatch and wage differences between the workers of Turkish public and private sectors, it is useful to look at the relationship of the two indicators. It has been argued that wage setting institutions explain the observed wage differences in the public sector, however, the wages in the private sector are mostly based on productivity (Allen et al., 2013). Therefore, education mismatches can be less influential on the former and associated wage penalties are expected to be greater in the latter. 


\section{Figure: 5}

\section{Wage Distribution across Sectors}

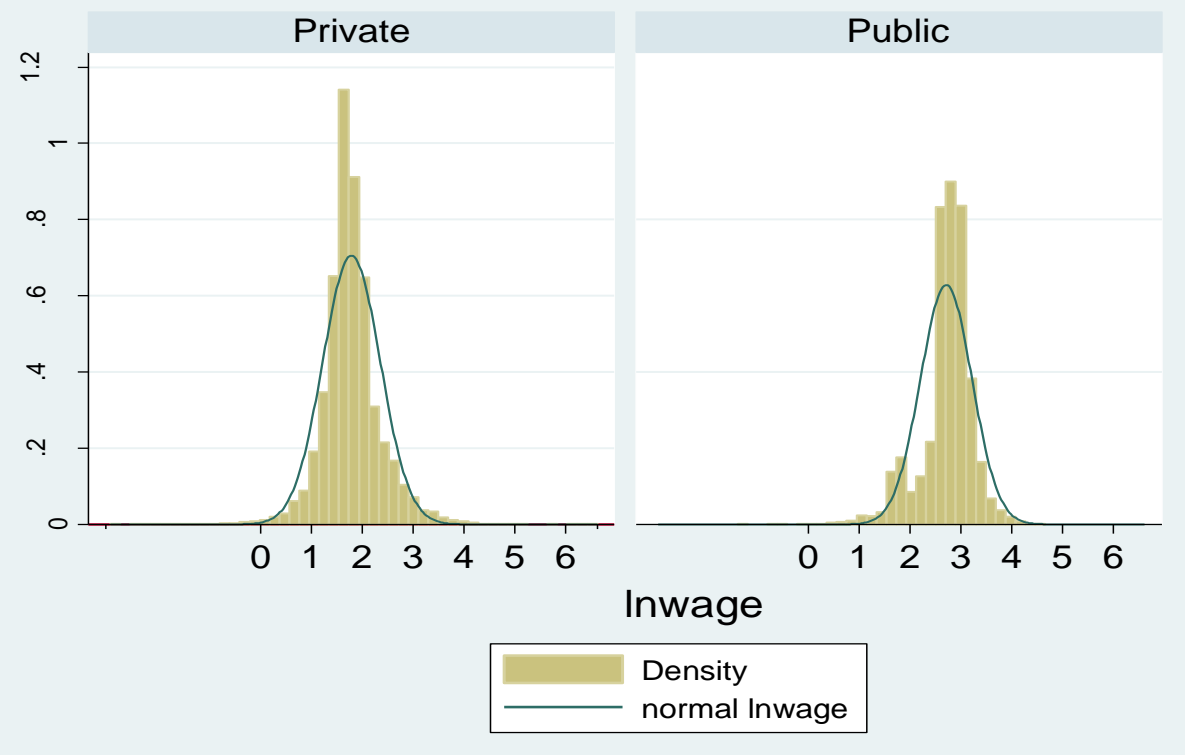

\section{Empirical Methodology and Findings}

\subsection{Methodology}

To estimate the impact of mismatches on wages we begin with a standard version of Mincerian model where education variable is decomposed into three parts; $E_{r}, E_{o}$ and $E_{u}$. The first term represents the required years of education whereas $E_{o}$ and $E_{u}$ measures the difference between the actual schooling of the employee and required level for their occupation (Duncan and Hoffman, 1981). For overeducated workers the years of schooling is the difference between their actual education and required education. On the other hand, for undereducated workers, the years are calculated by measuring the difference between actual and required education. To put it differently;

$$
\begin{aligned}
& E_{O}=\left\{\begin{array}{c}
E-E_{r} \text { if } E>E_{r} \\
0 \text { otherwise }
\end{array}\right. \\
& E_{u}=\left\{\begin{array}{c}
E_{r}-E \text { if } E_{r}>E \\
0 \text { otherwise }
\end{array}\right.
\end{aligned}
$$

Inserting the variables for overeducation and undereducation into the standard wage equation, we get:

$$
\text { lnhourwage }_{i}=\alpha_{i}+\alpha_{1} X_{i}+\alpha_{2} Y_{i}+\alpha_{3} E_{r}+\alpha_{4} E_{o}+\alpha_{5} E_{u}+\varepsilon_{i}
$$


where $\mathrm{X}$ is a vector of individual and household characteristics, $\mathrm{Y}$ is a vector of job characteristics, $E_{r}$ is required years of education, $E_{o}$ is years of overeducation, $E_{u}$ is years of undereducation and $\varepsilon$ is the error term. Schooling variables can also be measured as dummy variables, and this model examines the existence of wage penalty and premium instead of returns on years of schooling (Verdugo and Verdugo, 1989). According to this approach, individuals' actual education can be above, below or equal to the required level of education. Then, $E_{\mathrm{r}} E_{o}$ and $E_{\mathrm{u}}$ get a value of 1 if the employee has the required level of education, more than required level of education and less than required level of education respectively.

The wage differentials between individuals that are mismatched and matched are examined by Oaxaca decomposition technique. First, two equations are estimated for workers with required years of schooling and mismatched groups. Then, a counterfactual equation is formed that treats mismatched employees as matched. In the final stage, the wage differences are decomposed into characteristics and effects on these characteristics (Oaxaca, 1973). The first shows the part of wage gap that is due to endowment differences while the second identifies how these endowments are rewarded in labor markets. Hence, Oaxaca decomposition equation is a combination of characteristics and coefficients;

$$
\begin{aligned}
& \bar{W}_{m}-\bar{W}_{m i s}=\left(\bar{W}_{m}-\bar{W}_{m i s}^{*}\right)+\left(\bar{W}_{m i s}^{*}-\bar{W}_{m i s}\right) \\
& \bar{W}_{m}-\bar{W}_{m i s}^{*}=\beta_{m}\left(\bar{Z}_{m}-\bar{Z}_{m i s}\right) \\
& \bar{W}_{m i s}^{*}-\bar{W}_{m i s}=\left(\alpha_{m}-\alpha_{m i s}\right)+\left(\beta_{m}-\beta_{m i s}\right) \bar{Z}_{m i s}
\end{aligned}
$$

where $\bar{W}_{m}$ and $\bar{W}_{m i s}$ are the average wages that matched and mismatched employees receive in the market, and $\bar{Z}_{m}$ and $\bar{Z}_{m i s}$ captures the vector of individual and firm-level attributes such as age, gender, experience, marital status, firm size, social security registration, fulltime status and type of contract. $\bar{W}_{m i s}^{*}$ refers to the wage of mismatched workers using the intercept and coefficient from the matched worker equation. Then, $\left(\bar{W}_{m}-\bar{W}_{m i s}^{*}\right)$ indicates the wage differences as a result of different endowments between matched and mismatched employess, and $\left(\bar{W}_{m i s}^{*}-\bar{W}_{\text {mis }}\right)$ shows the unexplained wage gap or in other words the returns on endowments for matched and mismatched workers. We first calculate the effect of education mismatches on wages, then use Oaxaca decomposition method to analyze the earnings gap between these matched and mismatched groups for the entire sample and across sectors.

Control variables; age, gender, marital status, experience, full-time status, firm size, contract type and social security registration are also included in the wage equation and following decomposition. All of these variables are derived from several questions asked in HLFS. Gender, full-time status and social security registration are coded as dummy variables. Firm size is a categorical variable taking the value of 0 if there are less than 10 employees in the enterprise. Experience is calculated by subtracting the starting year of the job from the survey year. Lastly, regional dummy variables at NUTS-1 level and industry dummies according to NACE-2 Rev are added to the equation. 


\subsection{Impact of Education Mismatches on Wages}

The first model below utilizes a Mincerian model to inspect the returns to education in Turkish labor market. As can be seen from Table 1 all of the variables are highly explanatory and being employed in public sector has the highest coefficient with almost $45 \%$. This can be taken as a sign of sectoral divergences and in the next parts we divide the sample into public and private employees. On the other hand, temporary contracts, being a female and not being covered under social security negatively affects earnings by $9.5 \%$, $6.9 \%$ and $23.8 \%$ respectively. Our results shows that each year of education in Turkey is rewarded by nearly $20 \%$ of higher wages, which is quite substantial and hence it can be asserted that schooling is valuable. All of the coefficients are in line with the literature and have expected signs, with the exception of full-time status since being in a part-time position appears to increase wages by $27 \%$.

In the second model, education variable is disaggregated into three parts to capture mismatches in the labor market. While the coefficient on regular education is around $17.2 \%$, which is slightly higher than the previous regression. More notably, the return on overeducation is positive but lower than regular education. A year increase in overeducation raises wages by only $13 \%$, which is consistent with the other studies. The majority of the research found that overeducated employees are penalized in terms of earnings and this is also the case for Turkey as receiving schooling above required levels bring comparatively lower returns. Overeducated workers are able to have larger earnings than individuals with required schooling in similar occupations. However, their wages are below workers with the same years of schooling and are matched. Also, Turkish labor market is similar to other countries with regards to undereducation. The coefficient on undereducated workers is negative and reduces wages by $3.3 \%$. It should be noted that this group receives lower earnings than their matched counterparts in the same job but earn more than employees that have the same level of education. 
Table: 1

Estimation Results

\begin{tabular}{|c|c|c|}
\hline & Mincerian & Total \\
\hline Age & $\begin{array}{c}0.0076^{* *} \\
(0.0002)\end{array}$ & $\begin{array}{c}0.0068 * * \\
(0.0002)\end{array}$ \\
\hline Gender & $\begin{array}{c}-0.0698^{* *} \\
(0.0032)\end{array}$ & $\begin{array}{c}-0.0670^{* *} \\
(0.0032)\end{array}$ \\
\hline Marital Status & $\begin{array}{c}0.1228^{* *} \\
(0.0036)\end{array}$ & $\begin{array}{c}0.1130 * * \\
(0.0037)\end{array}$ \\
\hline Experience & $\begin{array}{c}0.0174 * * \\
(0.0006)\end{array}$ & $\begin{array}{l}0.0187 * * \\
(0.0006)\end{array}$ \\
\hline Experience2 & $\begin{array}{c}-0.0004^{* * *} \\
(0.0000)\end{array}$ & $\begin{array}{c}-0.0004^{* * *} \\
(0.0000)\end{array}$ \\
\hline Sector & $\begin{array}{c}0.4481 * * \\
(0.0040)\end{array}$ & $\begin{array}{c}0.4983 * * \\
(0.0040)\end{array}$ \\
\hline Full-Time Status & $\begin{array}{c}0.2733^{* *} \\
(0.0071)\end{array}$ & $\begin{array}{c}0.2980^{* * *} \\
(0.0072)\end{array}$ \\
\hline Firm Size & $\begin{array}{c}0.0601^{* *} \\
(0.0012)\end{array}$ & $\begin{array}{c}0.0605 * * \\
(0.0012)\end{array}$ \\
\hline Contract Type & $\begin{array}{c}-0.0951^{* * *} \\
(0.0049)\end{array}$ & $\begin{array}{c}-0.1147^{* * *} \\
(0.005)\end{array}$ \\
\hline Social Security & $\begin{array}{c}-0.2387^{* * *} \\
(0.0045)\end{array}$ & $\begin{array}{c}-0.2681 * * \\
(0.0045)\end{array}$ \\
\hline Education & $\begin{array}{c}0.1998^{* *} \\
(0.0013)\end{array}$ & \\
\hline Regular Education & & $\begin{array}{c}0.1723 * * \\
(0.0014)\end{array}$ \\
\hline Over Education & & $\begin{array}{c}0.1306 * * \\
(0.0012) \\
\end{array}$ \\
\hline Under Education & & $\begin{array}{c}-0.0331 * * \\
(0.0025)\end{array}$ \\
\hline Constant & $\begin{array}{c}0.5547 \\
(0.0115)\end{array}$ & $\begin{array}{c}0.6495 * * \\
(0.0012)\end{array}$ \\
\hline Region Dummies & $\mathrm{Y}$ & $\mathrm{Y}$ \\
\hline Industry Dummies & $\mathrm{Y}$ & $\mathrm{Y}$ \\
\hline \# of Observations & 94159 & 94159 \\
\hline R2 & 0.6039 & 0.5903 \\
\hline
\end{tabular}

** indicates $1 \%$ significance level and * indicates $5 \%$ significance level

Robust standard errors are in paranthesis

As discussed previously sectoral differences can be crucial for the relationship between education mismatches and earnings. The wage setting institutions and characteristics of workers across public and private sector can be substantially divergent. In Table 2, we look at the effect of education mismatches separately and the findings reveal clearly distinct outcomes for the Turkish case. Before we discuss the coefficients on years of schooling, it can be seen that being a female decreases wages by $8.8 \%$ in the private sector but its significance disappears in the public sector. Another variance emerges from the contract type and having a temporary position appears to be negatively related to earnings, however in private sector, it is not statistically explanatory. When it comes to education mismatches, the returns on regular education is computed to be approximately $19 \%$ in private sector. For the same sector, this goes down to $13 \%$ for overeducated workers and it has been found that wages are lowered by $7.7 \%$ for undereducated workers than their regular counterparts in the same job. Hence, our findings confirm human capital theory, which mainly argues that private sector determines wages according to labor productivity. 
Table: 2

Estimation Results across Sectors

\begin{tabular}{|c|c|c|}
\hline & Private & Public \\
\hline Age & $\begin{array}{c}0.0078^{* * *} \\
(0.0002)\end{array}$ & $\begin{array}{c}0.0067 * * * \\
(0.0004)\end{array}$ \\
\hline Gender & $\begin{array}{c}-0.0886^{* * *} \\
(0.0039) \\
\end{array}$ & $\begin{array}{l}-0.0046 \\
(0.005) \\
\end{array}$ \\
\hline Marital Status & $\begin{array}{c}0.1115^{* *} \\
(0.0043)\end{array}$ & $\begin{array}{c}0.0703 * * \\
(0.0061)\end{array}$ \\
\hline Experience & $\begin{array}{c}0.0151^{* *} \\
(0.0008)\end{array}$ & $\begin{array}{c}0.0091^{* *} \\
(0.0008)\end{array}$ \\
\hline Experience2 & $\begin{array}{c}-0.0002^{* *} * \\
(0.000)\end{array}$ & $\begin{array}{c}-0.0002^{* *} * \\
(0.000)\end{array}$ \\
\hline Full-Time Status & $\begin{array}{c}0.2901 * * \\
(0.0092)\end{array}$ & $\begin{array}{c}0.3486 * * \\
(0.0094)\end{array}$ \\
\hline Firm Size & $\begin{array}{c}0.0702^{* * *} \\
(0.0014)\end{array}$ & $\begin{array}{l}0.0051^{*} \\
(0.0022)\end{array}$ \\
\hline Contract Type & $\begin{array}{l}-0.0026 \\
(0.0056)\end{array}$ & $\begin{array}{c}-0.7262^{*} * \\
(0.0099)\end{array}$ \\
\hline Social Security & $\begin{array}{c}-0.2740^{* *} \\
(0.005)\end{array}$ & $\begin{array}{c}-0.5841^{* * *} \\
(0.015)\end{array}$ \\
\hline Regular Education & $\begin{array}{l}0.1891^{* * *} \\
(0.0017)\end{array}$ & $\begin{array}{c}0.1238^{* * *} \\
(0.0019)\end{array}$ \\
\hline Over Education & $\begin{array}{c}0.1295^{* * *} \\
(0.0015)\end{array}$ & $\begin{array}{c}0.1161^{* * *} \\
(0.0017)\end{array}$ \\
\hline Under Education & $\begin{array}{c}-0.0772^{* * *} \\
(0.003)\end{array}$ & $\begin{array}{c}0.0513^{* *} \\
(0.0046)\end{array}$ \\
\hline Constant & $\begin{array}{c}0.9760^{* *} \\
(0.015)\end{array}$ & $\begin{array}{c}2.9353 * * \\
(0.029)\end{array}$ \\
\hline Region Dummies & $\mathrm{Y}$ & $\mathrm{Y}$ \\
\hline Industry Dummies & $\mathrm{Y}$ & $\mathrm{Y}$ \\
\hline \# of Observations & 70898 & 23261 \\
\hline R2 & 0.3413 & 0.5785 \\
\hline
\end{tabular}

** indicates $1 \%$ significance level and * indicates 5\% significance level

Robust standard errors are in paranthesis

Contrarily, Turkish public sector displays a different relationship between mismatches and employee earnings. As can be seen from Table 2, one year incease in regular education brings about $12.4 \%$ rise in wages and the coefficient on overeducation is only slightly lower with $11.6 \%$. Even though, overeducated workers are penalized in public sector, the magnitude of penalty is less than private sector in Turkey. The most unexpected finding for Turkish case occurs for undereducated employees in public sector. In the literature, it has been widely asserted that workers with lower than required level of education should be earning less than their matched equivalents (Rubb, 2003). However, in Turkey, the coefficient on undereducation is positive and around $5.1 \%$ with a significance level of $1 \%$. This suggest that human capital theory might not be applicable to Turkish public sector, and wages are determined by different mechanisms. While undereducated workers are penalized by private firms as expected, they are able to receive higher wages in public sector. The findings are important for distinguishing the impact of mismatches and adequate policies to correct them. In private sector, emphasis should be given to overeducated workers whereas in public sector, main concern should be undereducated employees as their wage setting is not in line with their productivity.

To have a better understanding of earning differences between mismatched and matched employees, Oaxaca decomposition technique is utilized. Table 3 presents effect of characteristics, coefficients on the characterists and interaction terms for both sectors in 
Turkey. There is a major divergence between the wages for all groups across sectors. An overeducated employee manages to collect $2.874 \mathrm{TL}$ in terms of hourly logarithmic wages in public sector whereas this is merely 1.919 in private sector. The sectoral gap is even bigger for undereducated workers, which once again confirms our finding about the failure of human capital theory in explaining wage setting for Turkish public firms. An undereducated worker earns $2.168 \mathrm{TL}$ in public sector but this is reduced to $1.595 \mathrm{TL}$ for private sector employees. The wages for undereducated workers are even higher than the earnings of matched individuals in private sector, which is an indication of the generally low level of wages.

Between overeducated and matched employees, there is a wage difference of 0.143 in private sector. While endowments, firm and job attributes explain nearly $25 \%$ of this gap, $57.3 \%$ comes from the market returns on the features. The rest of the wage difference between these two groups emerges from the interaction between characteristics and coefficients, which is around $17.9 \%$. In terms of mismatch from undereducation, wage gap increases to 0.235 and almost $27.6 \%$ of this comes from the differences in endowments between regularly educated workers and undereducated workers. The share of coefficients is $78.4 \%$ and interaction term turns out to be negative suggesting a convergence across groups. For private sector employees, education mismatches are significant and a large portion of the earning differentials can be attributed to returns on characteristics. Since coefficients segment of Oaxaca decomposition describes the unexplained variance, it can be concluded that endowments, firm and job attributes are not sufficient to explain why mismatched and matched workers are treated differently in labor markets.

Table: 3

Oaxaca Decomposition

\begin{tabular}{|c|c|c|}
\hline & Private & Public \\
\hline \multicolumn{3}{|c|}{ Overeducation } \\
\hline Matched & 1.776 & 2.682 \\
\hline Mismatched & 1.919 & 2.874 \\
\hline Difference & -0.143 & -0.193 \\
\hline Characteristics & -0.035 & -0.029 \\
\hline Coefficients & -0.082 & -0.123 \\
\hline Interaction & -0.026 & -0.041 \\
\hline \multicolumn{3}{|c|}{ Undereducation } \\
\hline Matched & 1.830 & 2.778 \\
\hline Mismatched & 1.595 & 2.168 \\
\hline Difference & 0.235 & 0.611 \\
\hline Characteristics & 0.065 & 0.275 \\
\hline Coefficients & 0.184 & 0.195 \\
\hline Interaction & -0.014 & 0.141 \\
\hline
\end{tabular}

As can be observed from Table 3, decomposition results are distinct for public sector both in terms of absolute gaps and how they can be accounted for. Wage gap between overeducated public employees and matched ones are 0.193 and only $15.1 \%$ of this can be attributed to characteristics. In other words, gender, age, marital status, experience, social security, contract type, firm size, full-time status and social security registration can illuminate a small part of the existing wage differences between overeducated and matched employees in Turkish public sector. However, coefficients on these characteristics explain nearly $64 \%$, which means that these two groups receive highly varied returns to similar 
attributes. When we look at undereducated workers in public sector, wage gap between them and regularly educated individuals increase to 0.611 and $45 \%$ of it can be ascribed to endowments. This is a high share pointing toward the fact that mismatched workers have inferior labor market characteristics. The unexplained part is approximately $32 \%$ and the rest can be answered by the interaction term. Hence, it can be stated that returns on endowments, firm and job attributes are more equally treated between undereducated and matched workers in Turkish public sector. Yet, this might be due to wage setting mechanisms that are based on non-economic objectives.

\section{Conclusion}

Education mismatches in labor markets is considered to be major issue for a number of countries and our paper investigated the extent of mismatches in Turkey by using various measures. We found substantial ratios of overeducation and undereducation among Turkish workers, and in line with the literature, incidence of mismatch is higher with subjective estimates. Besides, it has been shown that there are sectoral differences and while undereducation is more common in private sector, overeducation is a bigger concern in public sector. Mean and mode measures give same results indicating that sectoral variation is robust to estimation techniques. The paper also looked at the wage impacts of education mismatches both for the entire sample and across sectors. Overall, education is valued in Turkish labor market and there are sizable returns to each year of schooling. However, similar to other country examples overeducated employees earn less than their actual level of education would bring in if they managed to get a job that matches with their training. On the contrary, undereducated workers receive higher wages than individuals with same schooling and have matching occupations. Moreover, we showed that education has positive returns for all employees as overeducated employees earn more and undereducated employees earn less than their co-workers, who have required level of education.

The paper also distinguished the impact of education mismatches on wages across sectors, and it has been found that undereducation has positive returns and overeducation is penalized less in public sector. This highlights the inapplicability of human capital theory for wage setting in the sector, and distinct wage setting mechanisms. In private sector, wage differences between overeducation and required education are smaller, and through Oaxaca decomposition method, it is revealed that most of it can be explained by coefficients. On the other hand, we revealed that wage gap in public sector for overeducated and matched employees can be attributed to coefficients. The difference in wages between undereducated and regularly educated workers is larger in public sector and the gap is mostly explained by endowments. In sum, there are considerable sectoral discrepancies with regard to education mismatches and their influence on wages. Given these, alternative policies should be developed to correct overeducation and undereducation in Turkey. For private sector, overeducation is more imminent, and given the high costs of human capital investments, occupation-worker match need to be achieved. In public sector wages should be aligned with productivity and undereducation shouldn't be rewarded. 
Duman, A. (2018), "Education Mismatches in the Labor Markets and Their Impact on Wages across Sectors: Evidence from Turkey", Sosyoekonomi, Vol. 26(37), 227-242.

\section{References}

Acar, E.Ö. (2016) "The Effects of Education-Job Mismatch on Wages: A Panel Analysis of the Turkish Labour Market", International Journal of Economics and Administrative Studies, (18), 339-354.

Allen, J. \& R. van der Velden (2001), "Education Mismatches versus Skill Mismatches”, Oxford Economic Papers, 53(3), 434-452.

Allen, J. \& R. van der Velden \& M. Levels (2013), "Skill mismatch and use in developed countries: Evidence from the PIAAC Study", University of Maastricht Working Paper, No. 13/061.

Duncan, G. \& S. Hoffman (1981), “The incidence and wage effects of overeducation”, Economics of Education Review, 1(1), 75-86.

El-Hamidi, F. (2009), "Education-Occupation Mismatch and the Effect on Wages of Egyptian Workers", Economic Research Forum Working Paper, No. 474.

Filiztekin, A. (2011), "Education-occupation mismatch in Turkish labor market", MPRA Paper, No. 35123.

Flisi, S. \& V. Goglio \& E.C. Meroni \& M. Rodrigues \& E. Vera-Toscano (2017), "Measuring Occupational Mismatch: Overeducation and Overskill in Europe - Evidence from PIAAC", Social Indicators Research, 131(3), 1211-1249.

Galasi, P. (2008), "The effect of educational mismatch on wages for 25 countries", Hungarian Academy of Science Working Paper, No. 2008/8.

Hartog, J. (2000), “Overeducation and Earnings: Where are we, where should we go?", Economics of Education Review, (19), 131-147.

ILO (2014), Skill Mismatch in Europe, Geneva: International Labour Organization.

Kiker, B. \& M. Santos \& M. de Oliveira (1997), "Overeducation and undereducation: evidence for Portugal", Economics of Education Review, 16(2), 111-125.

Leuven, E. \& H. Oosterbeek (2011), "Overeducation and Mismatch in the Labor Market", in: E. Hanushek \& S. Machin \& L. Woessmann (eds.), Handbook of the Economics of Education: Vol. 4, Amsterdam: Elsevier, 283-326.

McGoldrick, K. \& J. Robst (1996), "Gender Differences in Overeducation: A Test of the Theory of Differential Overqualification”, American Economic Review, 86, 280-284.

Mercan, M.A. \& M. Karakaş \& S.H. Çiftçi \& M. Babacan (2015), "Sector-Based Analysis of the Education-Occupation Mismatch in the Turkish Labor Market", Educational Sciences: Theory and Practice, 15(2), 1-11.

Meroni, E.C. \& E. Vera-Toscano (2017), “The Persistence of Overeducation among Recent Graduates", Labour Economics, (48), 120-143.

Oaxaca, R. (1973), "Male-female wage differentials in urban labor markets", International Economic Review, 14(3), 693-709.

Orbay, B. \& R. Aydede (2015), "Educational mismatch and the cost of underutilization in Turkish labourmarkets", MRPA Working Paper, No. 65713.

Rubb, S. (2003) "Overeducation in the labor market: A comment and re-analysis of a metaanalysis", Economics of Education Review, (22), 621-629.

Verdugo, R.R. \& N.T. Verdugo (1989), "The Impact of Surplus Schooling on Earnings: Some Additional Findings", Journal of Human Resources, 24(4), 629-643. 
Duman, A. (2018), "Education Mismatches in the Labor Markets and Their Impact on Wages across Sectors: Evidence from Turkey”, Sosyoekonomi, Vol. 26(37), 227-242.

Varhaest, D. \& E. Omey (2006), “The impact of overeducationand its measurement”, Social Indicators Research, (77), 419-448. 